\title{
试论学历继续教育内部教学质量监控体系的构建一一北京市 石景山区业余大学为例
}

\author{
朱国庆 \\ 北京市石景山区业余大学 \\ DOI:10.32629/er.v3i8.3102
}

\begin{abstract}
[摘 要] 学历继续教育是终身教育框架内的重要组成部分, 是培养社会急需应用型人才的重要途径, 学 校内部教学质量监拉体系的构建, 是实现应用型人才培养目标的重要保证,是提高区域性成人高校整体 应对激烈的市场竞争, 谋求更多教育资源及生存空间基本前提。本文以石景山区业余大学为例, 探讨学历 继续教育在全面质量管理理念指导下,内部教学质量监控体系的建立以及基本工作程序的形成,探索更 加科学合理的教学质量监控模式。
\end{abstract}

[关键词] 学历继续教育; 全面质量管理; 内部质量监控体系

中图分类号：G40-058 文献标识码：A

学历继续教育是当前我国终身教育 体系的重要组成部分, 是提升国民素质 的有效手段。学历继续教育质量的高低 直接关乎独立设置成人高校的生存与发 展。构建适合成人学历教育的质量监控 体系, 是确保提升成人学历教育质量的 基础性环节。石景山区业余大学是北京 石景山区独立设置成人高校, 自成立 40 年来, 在全面质量管理理念指导下, 不断 探索, 形成富有区域性特色继续教育教 学质量监控体系。

\section{1 学历继续教育内部教学质量} 监控体系的指导思想

20 世纪80年代末, 全面质量管理被 引入高等教育领域并对教学质量的提高 起到了积极的推动作用, 形成全面教学质 量管理监控体系。全面教学质量监控由五 个基本要素构成, 即顾客导向、全员参与、 监控体系、过程管理和持续改进。学生和 社会就是 “顾客”, 学校对内对外各种工 作必须以满足 “顾客” 需求为导向。

全面教学质量监控是学校全员参与 的一个系统工程。北京市石景山区业余大 学, 经过多年教学管理实践, 建立起一整 套较为完整的教学质量监控系统, 为学习 者所提供的学习支持服务由整个教学及
管理团队共同完成。系统中每一个岗位的 工作状态均决定着学校总体教学质量。

\section{2 石景山区业余大学内部教学} 质量监控体系的基本框架

内部教学质量监控体系是由各个相 互联系的子系统构成。不同高校由于自 身性质和工作特点不同, 其内部教学质 量监控体系的构成有一定的差别。对于 石景山业余大学而言, 一个完整的内部 教学质量监控体系应该由三个主要的子 系统构成, 即组织保障系统、质量标准系 统和过程监控系统。

石景山区业余大学在多年的教学实 践中, 探索建立符合以应用型人才培养 为目标, 教学内容以基于作过程为主导 的内部教学质量监控体系, 并已逐步形 成了以教学检查为主要形式的三级内部 监控体系和稳定的运行机制。

2. 1组织保障系统。组织机构保障系 统是指教学质量监控的决策和执行机构, 主要包括教学质量监控领导小组、教务、 教学等部门及其工作人员。石景山区业 余大学教学质量监控领导小组主要负责 教学质量监控制度和标准的建立, 以及 计划、方案的拟定。教务、教学部门主 要负责教学质量监控的具体实施。教务
部门又是教学质量监控的重要执行机构, 主要负责对教师的课程教学及考核计 划、新课试讲、教学进度、毕业设计指 导等教学活动的综合检查, 同时负责信 息的上传下达和部门间的协调。每学期 的期初、期中和期末, 校领导带领教研室 处室主任、教学管理员、教师、班主任 深入班级, 参与听课评课。

2. 2 质量标准系统。科学有效的内部 质量监控机制要求建立一套符合教育规 律, 切实可行的教学管理规章制度及一 系列覆盖面授教学、网上辅导、综合实 践环节指导以及考试等各个环节相互联 系、相互衔接及相互支持的质量标准。 石景山区业余大学围绕教学质量标准制 定了各项规章制度, 上至领导, 下至每一 位教职员工严格遵守规章制度, 切实保 障质量评价体系客观、公正、公平。

近十年来, 石景山区业余大学制定了 包括《教师岗位聘任考核办法》、《学期教 学检查管理办法》、《学校兼职教师管理规 定》《学校教务处工作流程》等一系列规 章制度, 2008年重新修订了《石景山区业 余大学教学管理制度汇编》, 共收入 31 项 教学管理制度及办法。同时这些制度又以 应用型人才培养为目标, 根据社会需求的 
变化, 对教学质量要求的变化进行动态调 整, 从而为教学质量监控提供依据。

2. 3过程监控系统。过程监控系统是 指教学质量监控中所开展的具体工作, 主 要包括常规教学检查、专项检査、督导检 查等。石景山区业余大学内部教学质量监 控主要开展集中听课、学生问卷调查、班 级座谈会、以及教学管理部门评价、教研 室教师之间的互评、及时反馈总结等五项 工作。集中听课包括 4 个环节: 教师说课、 小组听课、小组评课、教学部门反馈。其 中, 小组评价包括行政人员评价和教师评 价。学生问卷调查在全部教学班中进行, 分别对教师的教学态度、面授教学情况、 课后辅导情况、教学效果 4 个项目的 10 个 方面全方位调查。学生座谈会主要在不同 专业和年级中有针对性的召开。学期末, 教务处和教研室对教师进行评价考核最 后结合听课小组评价及学生评价得出教 师综合评价结果的量化分值。教学检查结 東后, 选择部分优秀的, 教学具有特色的 教师进行示范交流。

\section{3 石景山区业余大学内部教学 质量监控的基本工作程序}

PDCA循环是全面质量管理所应遵循 的科学程序。全面质量管理活动的全部过 程, 就是质量计划的制订和组织实现的过 程, 这个过程就是按照PDCA循环, 不停顿 地周而复始地运转的。它能使任何一项活 动有效进行的一种合乎逻辑的工作程序, 特别是在质量管理中得到了广泛的应用 并获得了显著成效。根据PDCA循环 (又称 戴明环), 石景山区业余大学内部教学质 量监控应分为四个基本阶段: 制定计划阶 段、实施监控阶段、检查总结阶段、评价 改进阶段, 主要包括八个步骤: 分析教学 质量监控现状, 找出问题、重点, 确定监控 目标; 制定教学质量监控计划, 明确职责; 实施具体监控工作, 及时反馈调整; 收集 监控数据, 及时跟踪督促; 检査总结监控 完成情况; 整理数据, 分析效果, 发现问 题; 评价教学质量监控结果, 分析成败; 推广成功经验, 整理遗留问题, 确定改进 目标。在戴明环质量管理的基本方法指导 下, 石景山区业余大学已构建起具有自身 特色教学质量监控工作程序。

\section{4 石景山区业余大学内部教学 质量监控取得的成效}

石景山业余大学构建的以教学检查 为主要形式的内部质量监控体系, 现已 取得了较为显著的效果:

4. 1 学校内部教学质量监控体系加 强了学校对教师的科学管理管理。石景 山业余大学教师管理打破传统模式, 变 身份管理为岗位管理。教师岗位共分 6 个岗级, 实行两年一聘。教师岗位聘任已 基本形成了能进能出, 能上能下的考评 机制。这一机制激励教师队伍整体业务 水平的提高, 教师的评聘已由达标上岗 过渡到此后的择优聘岗。

4. 2 学校内部教学质量监控体系提 高了教师队伍的整体水平。在 “促进学 生发展和教师提高”的评价理念指导下, 石景山业大教学质量评价标准的制定, 以学生发展为本, 力求反映成人教育教 学规律和成人学习特点, 力图鼓励教师 通过多样化的教学策略、方法和手段, 培养学生自学能力和实际操作能力, 促 进学生综合素质的全面提升。学校各专 业教师积极按照评价标准规定的内容完 成相应的教学任务。经过近十年的努力, 教师整体水平显著提高。

4. 3 学校内部教学质量监控体系满 足了学生实际需求。学生评教是检验教 师真实教学水平的重要标尺, 是以学生 为中心现代教育理念的充分体现。为保 证学生评教的客观性、真实性, 学校专门 开发了石景山区业余大学网上评教系 统。学生可以在任何时间、空间对教师 授课情况进行无记名打分, 系统后台自 动生成分值, 去除了人为干扰因素。学生 评教环节的分值占教师总体评价分值的 40\%, 而集中听课、教务处考评、教研室 评价三个环节所得出的分值只占到总分 值的 $60 \%$ 。由于学生评教分值权重较大, 促使教师更加注重教学方法的改进, 教 学手段更加多样化, 教学内容更加贴近 学生的实际需求。学生对教师的满意基 本稳定在高位。2006至2020年, 学生对教 师的平均满意率保持在 $85 \%$ 以上, 比 2001 至 2005 年平均满意率 $68 \%$ 提高 127 个百分点。
4. 4 学校内部教学质量监控体系提 升了学校的社会声誉。近15年来, 石景山 区业余大学秉持全面教学质量管理理念, 以培养应用型人才为奋斗目标, 努力提 升教学质量, 为学校赢得了良好的口碑。 从新生调查表反馈的信息可以得出这样 的结论, “到石景山业余大学学习, 不仅 能获得文凭, 更能学到实用技能。” 石景 山业余大学的幼儿艺术教育、会计等专 业的学生得到用人单位的好评; 学校每 学期举行的一次校园招聘会, 赢得了百 余家企业的青睐; 在招生工作中, 逐渐形 成了 “生传生, 生带生” 的良性循环, 学 历继续教育招生连续15年稳居北京市同 类院校前列。究其原因, 确保教学质量是 取得成功的关键, 构建成人学历教育内 部质量保障体系是学校取得良好社会声 誉的基石。

\section{5 结语}

《国家中长期教育改革和发展规划 纲要 (2010-2020年)》 (以下简称《规划纲 要》) 明确提出要稳步发展学历继续教育, 为今后成人高校的发展指明了前进方向。 提高学历教育质量是成人高校的核心工 作, 是践行《规划纲要》争取更广阔发展 空间的重要保障。实践证明, 在全面质量 管理理念指导下, 唯有不断完善学校内部 教学质量监控体系, 切实做到以质量立校, 才能使学历继续教育实现可持续发展, 完 成国家所赋予的历史使命。

\section{[参考文献]}

[1]付博.全人教育对成人高校教学 质量监控体系建设的启示 [J]. 黑龙江教 育学院学报,2018,37(11):41-43.

[2]李慧.高等学校教学质量监控体系 的构建与实施[J]. 林区教学,2020,(5):32-34.

[3]韩仪,崔明,奕斌, 等.国家开放大 学教学质量监控体系研究[J]. 福建广播 电视大学学报,2019,(05):13-19.

[4]魏然.构建地方高等院校教学质 量监控体系的实践研究 [J]. 高教学 刊,2020,(05):160-162.

[5]倪庚, 陈俊生,秦宇䑣,等. 基于全 面质量管理理论的本科教学质量监控工 作评价指标体系的构建 [J]. 教育理论与 实践,2019,39(33):15-16. 